\title{
ANALISIS KEBUTUHAN BAHAN AJAR BERBASIS ETNOMATEMATIKA YANG BERORIENTASI KETERAMPILAN BERPIKIR KREATIF
}

\author{
Sabina Ndiung ${ }^{1}$, Mariana Jediut ${ }^{2}$ \\ ${ }^{1,2}$ Universitas Katolik Indonesia Santu Paulus Ruteng \\ 1punyaku79@gmail.com
}

\begin{abstract}
Mathematics learning in elementary schools which is oriented to the formation of creative thinking skills has not become a priority for teachers in schools. This development research aims to produce ethnomathematical-based teaching materials that are Oriented to the formation of students' creative thinking skills on aspects of fluency, flexibility and originality. This research was conducted in Manggarai Regency involving 55 teachers from 11 subdistricts. The collection technique uses questionnaires related to needs analysis and also expert validation in terms of grammar and design. The results showed that in the aspect of material content there were $70.91 \%$ of teachers requiring ethnomathematical teaching materials. In the orientation aspect of creative thinking development, most teachers (90\%) want 1) teaching materials that include examples of problems that guide the formation of students' creative thinking skills; 2) contains student worksheets based on ethnopedagogical problems in this case the Manggarai culture; and 3) contains elements of traditional games; 4) contains the tools and materials needed to improve the ability of mathematical representation according to the context of the material presented. In the assessment aspect, $89.1 \%$ revealed that in measuring the achievement of student competence in geometry material, it was not yet oriented to measuring higher order thinking or HOTS and oriented to creative thinking. As in the aspect of the level of urgency of development, there are $92.73 \%$ giving the perception that the development of ethnomathematical-based teaching materials is very important. It can be concluded that it is important to develop ethnomathematical-based teaching materials according to the needs of teachers and students in Manggarai district and to shape the creative thinking skills of elementary school students.
\end{abstract}

Keywords: creative thinking skills; ethnomathematics; need analysis, teaching materials development

\begin{abstract}
Abstrak
Pembelajaran matematika di sekolah dasar yang berorrientasi pada pembentukan keterampilan berpikir kreatif belum menjadi skala prioritas guru di sekolah. Penelitian pengembangan ini bertujuan untuk menghasilkan bahan ajar berbasis etnomatematika yang berorientasi pada pembentukan keterampilan berpikir kreatif peserta didik pada aspek kefasihan, fleksibilitias dan originalitas. Penelitian ini dilaksanakan di Kabupaten Manggarai yang melibatkan 55 orang guru dari 11 kecamatan yang ada. Teknik pengumpulan menggunakan pengangketan yang berkenaan dengan analisis kebutuhan dan juga validasi pakar ditinjau dari ketatabahasaan dan desain. Hasil penelitian menunjukkan bahwa pada pada aspek konten materi terdapat 70,91\% para guru membutuhkan bahan ajar hasil etnomatematika. Pada aspek orientasi pengembangan berpikir kreatif, sebagian besar guru (90\%) menghendaki 1) bahan ajar yang menyertakan contoh-contoh masalah yang menuntun pembentukan keterampilan berpikir kreatif peserta didik; 2) memuat lembar kerja peserta didik (LKPD) yang berbasis masalah etnopedagogi dalam hal ini budaya Manggarai; dan 3) mengandung unsur permainan tradisional; 4) memuat alat dan bahan yang dibutuhkan untuk peningkatan kemampuan representasi matematis sesuai konteks materi yang disajikan. Pada aspek penilaian 89,1\% mengungkapkan bahwa dalam mengukur pencapaian kompetensi peserta didik pada materi geometri belum berorientasi pada pengukuran berpikir tingkat tinggi atau HOTS dan berorientasi pada berpikir kreatif. Pada aspek tingkat urgenitas pengembangan terdapat 92,73\% memberikan persepsi bahwa pengembangan bahan ajar berbasis etnomatematika sangat penting. Dapat disimpulkan bahwa pengembangan bahan ajar berbasis etnomatematika penting dilakukan sesuai dengan kebutuhan para guru dan siswa di kabupaten Manggarai serta membentuk keterampilan berpikir kreatif peserta didik sekolah dasar.
\end{abstract}

Kata Kunci: analisis kebutuhan; etnomatematika; keterampilan berpikir kreatif; pengembangan bahan ajar 


\begin{tabular}{llll}
\hline Received & $: 2021-06-09$ & Approved & $: 2021-07-30$ \\
Reviesed & $: 2021-07-29$ & Published & $: 2021-07-31$ \\
\hline
\end{tabular}

(c) (†) Jurnal Cakrawala Pendas is licensed under a Creative Commons Attribution-

ShareAlike 4.0 International License.

\section{Pendahuluan}

Pembelajaran matematika yang berorientasi pada pengembangan keterampilan berpikir kreatif belum menjadi orientasi para guru dalam pembelajaran matematika bagi peserta didik sekolah dasar (SD). Pendidikan saat ini harus berorientasi pada kompetensi pendidikan abad 21 yang mendorong individu kreatif dalam menyelesaikan masalah sehingga mampu bertahan hidup pada keadaan yang selalu berubah, tidak pasti, dan kompetitif (Ndiung, Dantes, Ardana, \& Marhaeni, 2019)(Ndiung \& Jediut, 2020; Ndiung, sariyasa, Jehadus, \& Apsari, 2021).

Kreativitas dan inovasi akan semakin berkembang jika peserta didik memiliki kesempatan untuk berpikir kreatif, yaitu berpikir di luar kebiasaan yang ada dengan cara berpikir berbeda dari biasanya (Scott, 2015) [3]. Dengan demikian, dibutuhkan suatu terobosan dalam pembelajaran matematika yang mampu membentuk keterampilan berpikir kreatif peserta didik dalam belajar. Mengingat, menurut Jean Piaget taraf perkembangan kognitif peserta didik SD masih berada pada operasional konkret sehingga dalam pembelajaran harus menampilkan suatu desain yang menarik dalam proses pembelajaran yang membuat peserta didik senang dalam belajar (Ardana, Ariawan, \& Divayana, 2017). Hal tersebut senada yang diungkapkan (Amir, 2015) bahwa matematika itu adalah seni dan jika diajarkan dengan menarik maka akan dirasakan sangat menyenangkan.

Salah satu terobosan pembelajaran matematika bagi guru matematika adalah mempelajari dan mengembangkan pembelajaran matematika yang berbasis etnomatematika. Dalam hal ini pengembangan bahan ajar berbasis etnomatematika yang berorientasi pada pembentukan keterampilan berpikir kreatif peserta didik khususnya di sekolah dasar yang mana selama ini belum menjadi skala prioritas. Kenyataan menunjukkan bahwa dalam pembelajaran matematika khususnya pada konsep geometri lebih banyak menyajikan contoh atau model bangun geometri baik bangun datar maupun bangun ruang yang kurang relevan dengan kehidupan peserta didik sehingga daya tarik pada pembelajaran matematika sangat kurang. Padahal, etnomatematika merupakan suatu ilmu yang digunakan untuk memahami bagaimana matematika diadaptasi dari sebuah budaya dan berfungsi untuk mengekspresikan hubungan antara budaya dan matematika.

Etnomatematika asdalah sebuah pendekatan pembelajaran matematika berbasis budaya lokal sehingga penelitian pengembangan etnomatematika dengan memunculkan karakteristik budaya setempat. Sehingga dapat dikatakan bahwa etnomatematika merupakan ilmu dalam mengkaji kebudayaan masyarakat, peninggalan sejarah yang terkait dengan matematika dan pembelajaran matematika (Marsigit, Condromukti, Setiana, \& Hardiarti, 2019; Richardo, 2016). Mempelajari etnomathematika, bukan berarti hanya mempelajari fenomena matematika dan menerjemahkannya ke dalam konsep matematika formal. Namun lebih dari itu, studi etnomathematika pada hakikatnya mempelajari tentang antropologi budaya (etnografi), pemodelan matematika dan matematika itu sendiri (Arisetyawan, Suryadi, Herman, \& Rahmat, 2014).

Secara material, obyek matematika itu berada di lingkungan atau sekitar peserta didik. Sedangkan secara formal, obyek matematika berupa benda-benda pikir. Benda-benda pikir diperoleh dari benda konkrit dengan malakukan abstraksi dan idealisasi (Marsigit et al., 2019). Makna-makna yang terungkap dari matematika material dan matematika formal itulah kemudian akan menghasilkan value atau nilai matematika. Seperti halnya Brooks \& Brooks yang dikutip oleh (Wahyuni, Aji, Tias, \& Sani, 2013) proses penciptaan makna melalui proses pembelajaran berbasis budaya memiliki beberapa komponen, yaitu tugas yang bermakna, 
interaksi aktif, penjelasan dan penerapan ilmu secara kontekstual, dan pemanfaatan beragam sumber belajar. Dalam pembelajaran berbasis budaya, budaya menjadi sebuah metode bagi siswa untuk mentransformasikan hasil observasi mereka ke dalam bentuk dan prinsip yang kreatif tentang bidang ilmu.

Etnomatematika yang melekat dengan simbol-simbol budaya Manggarai seperti konsep bangun datar menyerupai pembagian lingko lodok (model lingkaran atau webbed rice), pernakpernik tarian caci, serta alat music tradisional. Sementara, model bangun ruang menyerupai model mbaru gendang untuk konsep limas, mbaru niang (rumah adat) untuk konsep kerucut, model compang (mesbah), roto (keranjang) untuk konsep tabung, dan lainnya. Seperti halnya (Juano \& Jediut, 2019) mengungkapkan bahwa bentuk-bentuk etnomatematika budaya Manggarai dapat dieksplore melalui kegiatan menenun, upacara adat, anyaman, pelengkapan rumah tangga, bangunan, kegiatan betani, dan alat musik tradisional. Demikian halnya (Tamur, Sennen, \& Pantaleon, 2017) menunjukkan bahwa etnomatematika terlihat dan tertanam dalam tradisi be'lis dan pengukuran serta membilang.

Penelitian terkait pengembangan bahan ajar berbasis etnomatematika telah banyak dilakukan oleh peneliti sebelumnya. Penelitiannya (Marsigit et al., 2019) menunjukkan bahwa pengembangan perangkat pembelajaran berbasis etnomatematika dapat memberi solusi kepada guru matematika untuk melakukan inovasi pembelajaran matematika. Demikian halnya (Muzdalipah \& Yulianto, 2015) menunjukkan bahwa potensi etnomatematika dari permainan tradisional masyarakat Kampung Naga yang terdiri dari congklak, galah dan pecle bisa dikembangkan sebagai konteks matematika yang bisa dikembangkan dalam pembelajaran. Hal ini dikarena permainan-permainan tradisional yang berkembang di sana mengandung konsepkonsep matematika. Selanjutnya, (Rosilia, Yuniawatika, \& Murdiyah, 2020), guru membutuhkan bahan ajar lain yang memiliki materi pembelajaran yang luas dan terdapat latihan soal di dalamnya, 2) sebagian besar siswa kelas III membutuhkan bahan ajar pendamping yang dapat digunakan untuk belajar mandiri. Temuan penelitiannya (Rohmaini, Netriwati, Komarudin, Nendra, \& Qiftiyah, 2020) menunjukkan bahwa modul pembelajaran berbasis etnomatematika berbantuan Wingeom pada materi bangun ruang sisi lengkung yang dikembangkan berdasarkan hasil uji coba sangat menarik sehingga dapat dikembangkan untuk cakupan materi yang lebih luas. Demikian halnya (Nadhilah, Purwoko, Nugraheni, Purworejo, \& Purworejo, 2020) menunjukkan bahwa bahan ajar seperti modul berbasis elektronik perlu dikembangkan karena tidak selamanya siswa belajar menggunakan bahan ajar pada umumnya, diharapkan dengan menggunakan bahan ajar yang menyenangkan seperti modul elektronik, siswa mampu mengubah opini dan pandangan mereka bahwa matematika merupakan mata pelajaran yang sulit tetapi menyenangkan. Sementara itu, untuk materi segiempat dapat disusun dengan menerapkan etnomatematika ke dalamnya yaitu produk budaya budaya Jawa Tengah.

Pengambangan ini berorientasi pada pembentukan keterampilan berpikir kreatif peserta didik sekolah dasar pada materi geometrid an pengukuran. keterampilan berpikir kreatif adalah kemampuan yang dimiliki seseorang yang berhubungan dengan aktivitas mental yang terkait dengan kepekaan terhadap suatu masalah, mempertimbangkan informasi baru dan ide-ide yang tidak biasanya dengan suatu pikiran terbuka, serta dapat membuat hubungan-hubungan dalam menyelesaikan suatu masalah (La Moma, 2015; Vale \& Barbosa, 2015). Seseorang dikatakan memiliki keterampilan berpikir kreatif jika memenuhi empat indikator berpikir kreatif yaitu fluency (lancar/fasih), flexibility (luwes), originality (orisinal), dan elaboration (memperinci) (Sanders, 2016). Penelitian ini dilakukan pada peserta didik sekolah dasar, oleh karena pada tingkat ini peserta didik belum mampu berpikir abtrak yang tidak memungkinkan indikator elaboraration (memperinci) dapat diselesaikan dengan perkembangan kognitif anak pada masa ini. Oleh karena itu, dalam penelitian ini, seorang peserta didik dikatakan memiliki keterampilan berpikir kreatif jika memenuhi tiga aspek keterampilan berpikir kreatif yaitu aspek fluency (lancar) dengan ciri mampu menghasilkan lebih banyak gagasan dalam menyelesaikan masalah, aspek flexibility (luwes) dengan ciri memberi cara menyelesaikan masalah dengan cara yang beragam, dan aspek originality (orisinal), yaitu memiliki gagasan atau cara berpikir yang tidak lazim atau lain dari yang lain.

Dari beberapa hasil penelitian terdahulu menunjukkan bahwa pengembangan bahan 
ajar berbasis etnomatematika penting dikembangkan untuk memberi solusi kepada guru matematika untuk melakukan inovasi pembelajaran matematika, sebagai bahan ajar pendamping yang dapat digunakan untuk belajar mandiri, dapat memahamkan konsep geometri. Sehingga diduga dengan pengembangan bahan ajar etnomatematika mampu meningkatkan pembentukkan keterampilan berpikir kreatif. Atas dasar itu, pengembangan ini urgen dilakukan untuk menuntun para guru SD untuk melatih peserta didik memecahkan masalah matematika secara kreatif yang selama ini belum menjadi prioritas. Dengan demikian, diperlukan suatu bahan ajar yang dapat membentuk keterampilan berpikir kreatif peserta didik yaitu sumber belajar matematika berupa bahan ajar yang mampu mengintegrasikan budaya ke dalam matematika atau sering dinamakan sebagai etnomatematika.

Penelitian ini bertujuan untuk mengetahui kebutuhan yang diperlukan oleh para guru dan siswa di kabupaten Manggarai sebelum tersusunnya bahan ajar berbasis etnomatematika salah satu wujud pembelajaran matematika berbasis budaya pada siswa sekolah dasar. Selain itu, pengembangan ini bertujuan untuk membentuk keterampilan berpikir kreatif peserta didik sekolah dasar dengan memfasilitasi para guru sekolah dasar dengan pengetahuan etnomatematika dengan mengintegrasikan produk budaya Manggarai ke dalam pembelajaran matematika.

\section{Metode Penelitian}

Penelitian ini merupakan penelitian kualitatif dengan menggunakan metode deskriptif kualitatif yang berorientasi pada pengembangan suatu produk. Prosedur penelitian ini mengacu pada Borg \& Gall yang dimodifikasi (Pratomo, Sunardo, \& Siskandar, 2016) di mana pengembang memodifikasnya sesuai alir penelitian ini, yaitu: 1) analisis kebutuhan lapangan., 2) mengolah data dan menginterpretasikan data analisis kebutuhan; 3) Merancang desain pengembangan produk berdasarkan hasil analisis kebutuhan; 4) Mengembangkan produk; 5) Validasi produk oleh para pakar; 6) Re-desain produk pengembangan; 7) uji coba lapangan; 8) analisis dan intepretasi Data; 9) Revisi uji coba produk final untuk memperoleh produk final; dan 10) diseminasi

Penelitian ini merupakan hasil kolaborasi dengan dengan dinas pendidikan kabupaten Manggarai. Oleh karena itu, Subjek dalam penelitian ini adalah 55 orang guru sekolah dasar sekabupaten Manggarai yang tersebar dalam 11 kecamatan dengan penyebaran secara merata 5 responden per kecamatan. Responden-responden tersebut tersebar pada 5 sekolah per kecamatan untuk memperoleh data secara komprehensif dan representatif. Penelitian ini termasuk dalam skala besar mengingat dinas pendidikan kabupaten Manggarai menghendaki adanya luaran berupa produk bahan ajar berbasis etnomatematika sebagai bahan referensi yang akan didistribusikan kepada seluruh satuan pendidikan yang ada di kabupaten Manggarai. Sementara, objek dalam penelitian ini adalah bahan ajar berbasis etnomatematika yang berorientasi pada pembentukan keterampilan berpikir kreatif.

Teknik pengumpulan data dalam penelitian ini menggunakan teknik wawancara. Mengingat, penelitian ini dilaksanakan pada masa pandemi Covid-19 sehingga tidak memungkinkan adanya pertemuan tatap muka dalam melakukan wawancara, maka peneliti menggunakan wawancara terstruktur dengan menggunakan google formulir dengan metode pengisian menggunakan jawaban panjang atau paragraph untuk memperoleh data seautentik mungkin. Banyaknya item pertanyaan yang diajukan adalah 11 butir yang dikelompokkan ke dalam 4 aspek utama yaitu konten materi, orientasi pengembangan, penilaian dan tingkat urgenitas pegembangan. Teknik analisis data menggunakan Analysis Interactive dari Miles \& Huberman (Emzir, 2014: 134), analisis terdiri dari tiga alur kegiatan yang terjadi secara bersamaan yaitu: reduksi data, penyajian data, penarikan kesimpulan/verifikasi. 


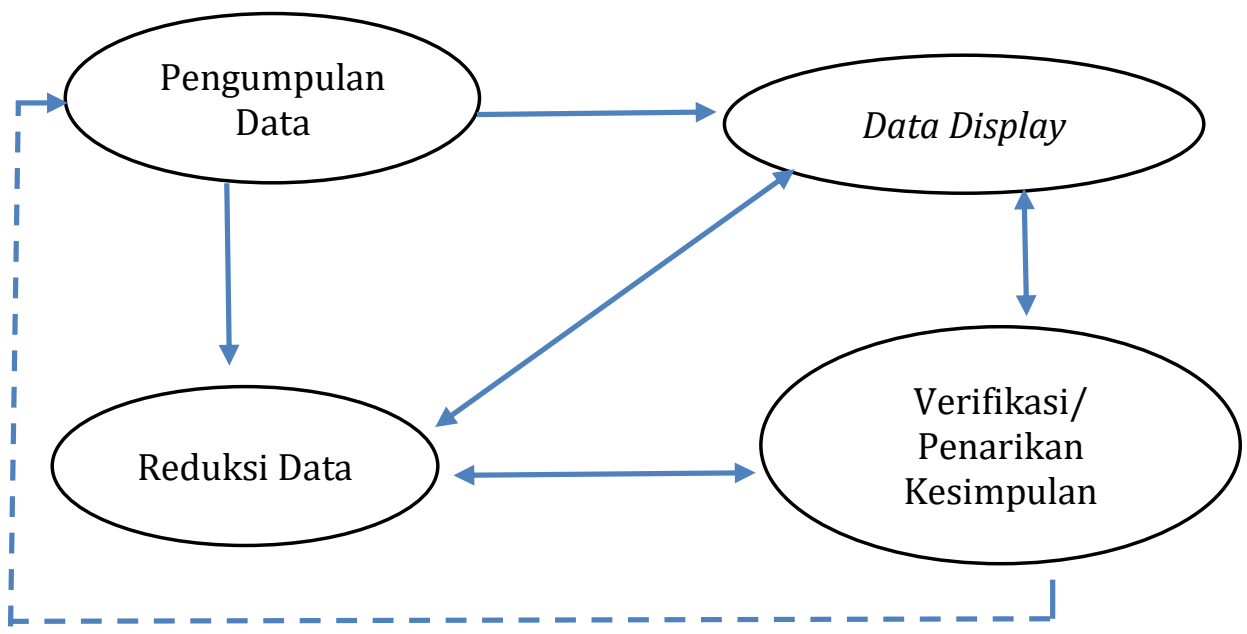

Gambar 1. Model Analisis Interaktif

Gambar di atas menggambarkan prosedur analisis data pada penelitian ini. Adapun urutan langkahnya adalah sebagai berikut; (1) mengidentifikasi dan mencatat semua temuan fenomena melalui observasi dan wawancara kepada sampel penelitian yaitu 55 orang guru sekabupaten dengan 5 orang per kecamatan. Hal ini dilakukan untuk mengetahui analisis kebutuhan bahan ajar yang akan dikembangkan berupa bahan ajar berbasis etnomatematika yang berorientasi pada pengembangan keterampilan berpikir kreatif, (2) setelah pengumpulan data, selanjutnya data direduksi dengan analisis yang menajamkan, menggolongkan, mengarahkan, membuang yang tidak perlu, dan mengorganisasi data dengan cara sedemikian rupa hingga kesimpulan-kesimpulan finalnya dapat ditarik kesimpulan dan diverifikasi, (3) melakukan Focus Group Discussion untuk memperoleh input atau informasi terkait kesesuaian data yang dikumpulkan sebelum data diklasifikasi dan dianalisis lanjut, (4) mendeskripsikan data yang telah diklasifikasikan dengan memperhatikan fokus dan tujuan penelitian, dan (5) membuat analisis akhir dalam bentuk laporan hasil penelitian.

Selanjutnya, untuk validasi produk oleh para pakar yaitu ahli Bahasa dan ahli media dilakukan dengan mengelompokkan informasi-informasi dari data kualitatif berupa masukan, tanggapan, kritikan, dan saran perbaikan yang sudah disediakan pada angket. Hasil analisis digunakan untuk merevisi produk model pengembangan pembelajaran yaitu menggunakan analisis Statistik Deskriptif yaitu untuk mengolah data yang diperoleh melalui angket dalam bentuk deskriptif persentase. Teknik ini menggunakan rumus sebagai berikut:

$$
\text { Persentase tingkat validasi produk }=\frac{\sum \text { Skor perolehan }}{\text { Skor Maksimal }} \times 100 \%
$$

Untuk menemukan kesimpulan yang telah dicapai, maka ditetapkan kriteria sesuai dengan Tabel tingkat validasi berikut

Tabel 1. Tingkat Validasi Produk oleh Pakar

\begin{tabular}{ccl}
\hline Persentasi (\%) & Kualifikasi & Keterangan \\
\hline $90-100$ & Sangat Baik & Tanpa Revisi \\
$75-89$ & Baik & Revisi Minor \\
$65-74$ & Cukup & Revisi Sebagian \\
$55-64$ & Kurang & Revisi Mayor \\
$0-54$ & Sangat Kurang & Revisi Total \\
\hline
\end{tabular}




\section{Hasil dan Pembahasan}

Analisis kebutuhan pengembangan bahan ajar berbasis etnomatematika yang berorientasi pada pembentukkan keterampilan berpikir kreatif mengacu pada kondisi empiris di sekolah dasar se-kabupaten Manggarai. Mengingat, penelitian ini dilakukan di sekolah dasar maka data dikumpulkan mengacu pada informasi yang diberikan oleh 55 orang guru SD sebagai responden yang tersebar pada 11 kecamatan menggunakan angket analisis kebutuhan melalui pengisian google formulir.

Berikut merupakan Tabel Ringkasan data respons para guru terkait analisis kebutuhan terhadap bahan ajar etnomatematika di sekolah dasar.

Tabel 2.Rekapitulasi Data Analisis Kebutuhan

\begin{tabular}{|c|c|c|c|}
\hline Aspek Analisis & $\begin{array}{l}\text { Jumlah } \\
\text { Responden }\end{array}$ & $\begin{array}{l}\text { Persentasi } \\
(\%)\end{array}$ & Rekemendasi pengembangan \\
\hline Konten Materi & 39 & 70,91 & $\begin{array}{l}\text { Membutuhkan bahan ajar hasil } \\
\text { etnomatematika pada materi geometri dan } \\
\text { pengukuran. }\end{array}$ \\
\hline $\begin{array}{l}\text { Orientasi } \\
\text { pengembangan } \\
\text { berpikir kreatif }\end{array}$ & 50 & 90,91 & $\begin{array}{l}\text { 1) Memuat contoh-contoh masalah yang } \\
\text { berorientasi HOTS } \\
\text { 2) Memuat LKPD berpikir kreatif }\end{array}$ \\
\hline & & & $\begin{array}{l}\text { 3) Mengandung unsur permainan } \\
\text { tradisional } \\
\text { 4) Memuat alat dan bahan representasi } \\
\text { matematis }\end{array}$ \\
\hline Penilaian & 49 & 89,1 & Penilaian berorientasi HOTS \\
\hline $\begin{array}{l}\text { Tingkat urgenitas } \\
\text { Pengembangan }\end{array}$ & 51 & 92,73 & $\begin{array}{l}\text { Sangat mendesak sebagai bagian dari } \\
\text { aktivitas mengembalikan pengetahuan atau }\end{array}$ \\
\hline & & & $\begin{array}{l}\text { pengalaman budaya yang hampir } \\
\text { terlupakan }\end{array}$ \\
\hline
\end{tabular}

Hasil analisis data berdasarkan pengisian angket analisis kebutuhan yang didukung oleh hasil FGD dengan 55 orang guru dari 11 kecamatan di Kabupaten Manggarai menunjukkan bahwa pada aspek konten materi terdapat $70,91 \%$ para guru membutuhkan bahan ajar hasil etnomatematika karena muatan konten pada buku guru dalam kurikulum 2013 tidak cukup memadai berkenaan dengan penyajian materi geometri. Selain itu, selama ini dalam penyajian materi geometri dan pengukuran lebih mengaitkan pada konteks siswa namun belum menggunakan etnomatematika.

Demikian halnya pada aspek orientasi pengembangan berpikir kreatif, sebagian besar guru (90\%) menghendaki 1) bahan ajar yang menyertakan contoh-contoh masalah yang menuntun pembentukan keterampilan berpikir kreatif peserta didik; 2) memuat lembar kerja peserta didik (LKPD) yang berbasis masalah etnopedagogi dalam hal ini budaya Manggarai; dan 3) mengandung unsur permainan tradisional; 4) memuat alat dan bahan yang dibutuhkan untuk peningkatan kemampuan representasi matematis sesuai konteks materi yang disajikan. Hal ini dibutuhkan mengingat selama ini baik pada proses pembelajaran matematika maupun LKPD belum disajikan secara mendetail terkait melatih pemecahan masalah yang berorientasi pada proses berpikir kreatif peserta didik. Hal ini sejalan dengan penelitianya (Monda Nova Pratiwi, 2018) menunjukkan bahwa siswa mengalami kesulitan pada materi koordinat dan cartesius sehingga hasilnya kurang maksimal, kemampuan berpikir kreatif siswa masih rendah, bahan ajar sehingga bahan ajar berupa modul matematika yang dikembangkan layak digunakan dalam proses pembelajaran matematika. Selain itu, pengembangan ini relevan dengan temuan penelitiannya (Rosilia et al., 2020) yang mencerminkan bahwa guru dan siswa kelas III SDN Bendogerit 2 membutuhkan bahan ajar pendamping untuk melengkapi buku pokok. Bahan ajar pendamping yang dibutuhkan adalah bahan ajar yang memiliki materi yang luas dan memuat latihan soal. Demikian halnya penelitian yang dilakukan (Arnawa \& Fauzan, 2018) menunjukkan bahwa peneliti perlu mengembangkan pembelajaran matematika model berbasis 
pendidikan matematika realistik dan literasi di SMP hal ini disebabkan oleh 1) pengetahuan guru tentang literasi matematika rendah, 2) pendekatan pembelajaran masih belum mengaitkan materi dengan konteks keseharian siswa kehidupan, 3) nilai rata-rata literasi matematika siswa adalah 31,87 diklasifikasikan menjadi kategori rendah, dan 4) instrumen penilaian jauh dari literasi matematika, 5) pendekatan pendidikan matematika realistik yang pernah dikembangkan peneliti dalam pembelajaran matematika belum dipadukan dengan konsep literasi.

Selanjutnya, pada aspek penilaian $89,1 \%$ mengungkapkan bahwa dalam mengukur pencapaian kompetensi peserta didik pada materi geometri dan pengukuran belum berorientasi pada pengukuran berpikir tingkat tinggi atau HOTS apalagi yang berorientasi pada berpikir kreatif. Yang terjadi selama ini adalah lebih pada pencapaian kompetensi menggunakan soalsoal rutin sebagai feedback terhadap pengusaan konsep yang telah dipelajari. (Andini \& Fitriana, 2018) menunjukkan bahwa kemampuan siswa yang menggunakan flipbook lebih baik dibandingkan dengan siswa yang tidak menggunakan flipbook dalam pembelajaran geometri. Dalam hal ini multimedia flipbook lebih ampuh (unggul) dibandingkan dengan produk sebelumnya. Seperti halnya pada aspek tingkat urgenitas pengembangan terdapat $92,73 \%$ memberikan persepsi bahwa pengembangan bahan ajar berbasis etnomatematika sangat penting. Yang mana bahwa guru mengungkapkan pentingnya mengembangkan bahan ajar yang mampu mengukur keterampilan berpikir tingkat tinggi bagi siswa yaitu berkenaan dengan berpikir kritis dan berpikir kreatif tidak hanya berorienntasi pada kemampuan komputasi saja tetapi lebih melatih siswa menyelesaikan masalah dan keterampilan berpikir. Selain itu, para guru memberikan rekomendasi kepada pengembang agar melakukan sosialisasi terhadap produk pengembangan untuk pengetahuan etnomatematika yang lebih mendalam sebagai bagian dari aktivitas mengembalikan pengetahuan atau pengalaman budaya yang hampir terlupakan. Demikian halnya dengan produk berupa bahan ajar perlu didistribusikan kepada sekolah-sekolah di kabupaten Manggarai agar semua para guru memiliki pemahaman yang sama tentang etnomatematika. Adapun model-model yang dapat digunakan dalam pembelajaran geometri berbasis etnomatematika diantaranya sebagai berikut.
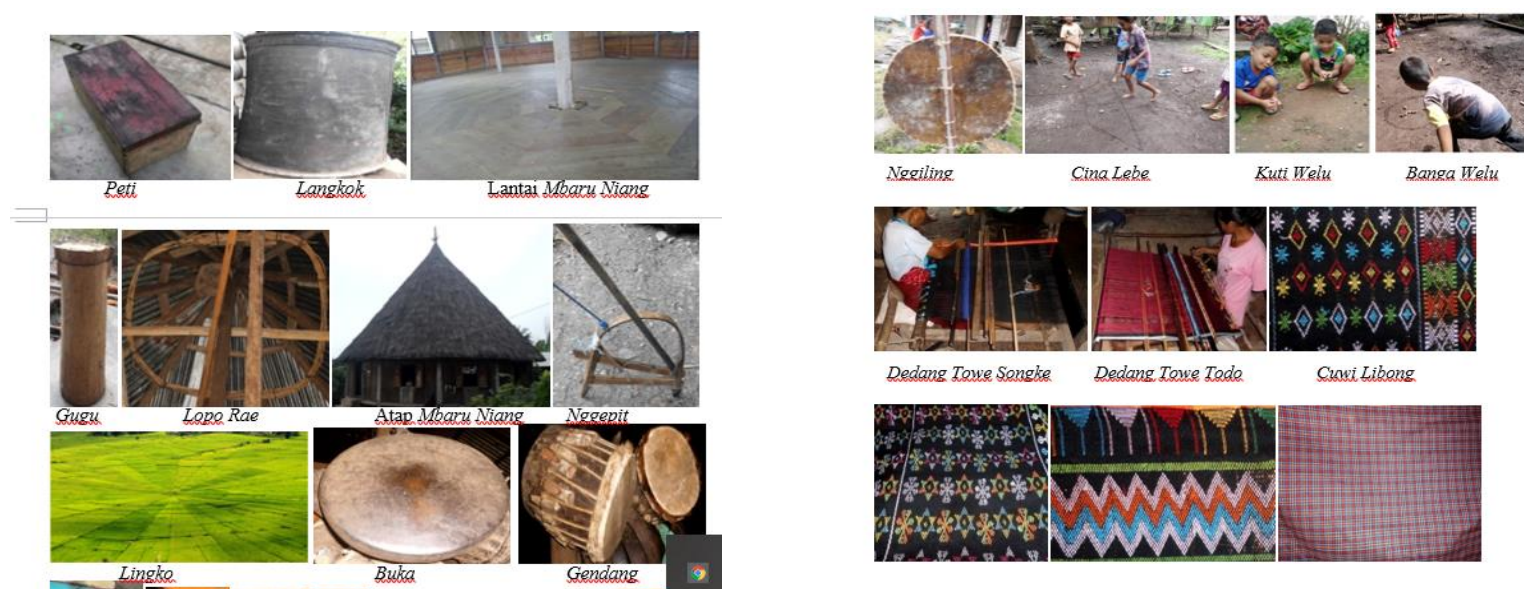

Gambar 2. Model Etnomatematika Kabupaten Manggarai

Selanjutnya, hasil validasi produk pengembangan oleh pakar dengan menggunakan instrument validasi produk oleh pakar menunjukkan bahwa produk pengembangan layak digunakan dengan tanpa revisi yang mana persentasi penilaiannya berada pada interval $90 \%$ $100 \%$ dengan kualifikasi sangat baik dan rekomendasi tanpa revisi. Dengan demikian produk pengembangan ini siap untuk diujicoba. Mengingat, penelitian ini dilakukan ditengah pandemic Covid-19 yang tidak memungkinkan untuk pertemuan tatap muka karena adanya kebijakan belajar dari rumah (BDR) maka uji coba lapangan dilakukan setelah proses pembelajaran di kelas kembali normal. 
Berdasarkan data hasil penelitian yang telah diuraikan di atas, maka para guru merekomendasikan bahwa pengembangan bahan ajar berbasis etnomatematika sangat penting dilakukan untuk mendekatkan peserta didik dengan situasi pembelajaran yang dekat dengan kehidupan mereka. Pengembangan bahan ajar etnomtematika pada materi geometri bangun datar dan bangun ruang yang berorientasi pada keterampilan berpikir kretif penting dilakukan. Hal ini didukung oleh penelitiannya (Ndiung, Sennen, Helmon, \& Jediut, 2020) menunjukkan bahwa penggunaan model pembelajara Treffinger mampu meumbuhkan keterampilan berpikir kreatif peserta didik. Selain itu, porses berpikir perlu dibentuk melalui pendekatan yang mendukung kemampuan pemecahan masalah yang melatih proses berpikir seperti penelitiannya (Ripai \& Sutarna, 2020) menunjukkan bahwa penggunaan model pembelajaran PBL berbantuan Macromedia flash cukup efektif untuk meningkatkan kemampuan pemecahan masalah pada siswa kelas IV sekolah dasar.

Temuan penelitian ini didukung oleh (Sukmawarti \& Pulungan, 2020) yang menunjukkan bahwa Pengembangan bahan ajar pada materi geometri untuk siswa kelas IV SD dilakukan dengan mengadopsi prosedur pengembangan $A D D I E$ dan tahap evaluasi termasuk dalam kateogori baik. Selanjutnya, (Monda Nova Pratiwi, 2018) bahan ajar berupa modul matematika yang dikembangkan yang berorientasi pada kemmpun berpikir kritis dan kreatif layak digunakan dalam proses pembelajaran matematika. Demikian halnya (Nadhilah et al., 2020) menunjukkan bahwa hasil studi literatur dan studi lapangan menunjukkan bahwa perlu dikembangkan bahan ajar e-modul berbasis etnomatematika produk budaya Jawa Tengah. Demikian halnya (Rohmaini et al., 2020) menunjukkan bahwa modul pembelajaran yang dikembangkan memiliki kriteria layak/valid dan menarik untuk digunakan sebagai sumber belajar dalam pembelajaran matematika.

\section{Kesimpulan}

Berdasarkan dengan hasil penelitian dan pembahasan dapat ditarik kesimpulan bahwa pengembangan bahan ajar berbasis etnomatematika penting dilakukan sesuai dengan kebutuhan para guru dan siswa di kabupaten Manggarai serta membentuk keterampilan berpikir kreatif peserta didik sekolah dasar dengan memfasilitasi para guru sekolah dasar pengetahuan etnomatematika dengan mengintegrasikan produk budaya Manggarai ke dalam pembelajaran matematika. Penelitian pengembangan ini telah menghasilkan sebuah bahan ajar berbasis etnomatematika yang berorientasi keterampilan berpikir kreatif yang layak digunakan dalam meningkatkan proses berpikir dan pembentukan keterampilan berpikir kreatif yag dilengakapi dengan LKPD, dan soal-soal berpikir kreatif.

\section{Daftar Pustaka}

Amir, Z. (2015). Mengungkap Seni Bermatematika dalam Pembelajaran, 1(1), 60-76.

Andini, S., \& Fitriana, L. (2018). Developing FipBook Multimedia: TheAchievement of Informal Deductive Thinking Leve. Journal on Mathematics Education, 9(2), 227-238.

Ardana, I. M., Ariawan, I. P. W., \& Divayana, D. G. H. (2017). Measuring the effectiveness of blcs model (bruner, local culture, scaffolding) in mathematics teaching by using expert system-based cse-ucla. International Journal of Education and Management Engineering, 7(4), 1-12. https://doi.org/10.5815/ijeme.2017.04.01

Arisetyawan, A., Suryadi, D., Herman, T., \& Rahmat, C. (2014). Study Ethnomathematics : A Lesson of Baduy Culture. International Journal of Education and Research, 2(10), 681-688.

Arnawa, M., \& Fauzan, A. (2018). The need analysis development of mathematics learning model based realistic mathematical education and literacy in junior high school The need analysis development of mathematics learning model based realistic mathematical education and literacy in junior, (January). https://doi.org/10.29210/2018113

Juano, A., \& Jediut, M. (2019). Dalam Budaya Masyarakat Manggarai. Jurnal Pendidikan Dan Kebudayaan Missio, 11(2), 179-316.

La Moma. (2015). Pengembangan Instrumen Kemampuan Berpikir Kreatif Matematis. DeltaPi: Journal Matematika Dan Pendidikan Matematika, 4(1), 27-41. Retrieved from 
http://garuda.ristekdikti.go.id

Marsigit, Condromukti, R., Setiana, D. S., \& Hardiarti, S. (2019). Pengembangan Pembelajaran Matematika Berbasis Etnomatematika. Journal of Chemical Information and Modeling, 20-38.

Monda Nova Pratiwi. (2018). Analisis Kebutuhan Bahan Ajar Matematika untuk Meningkatkan Berpikir Kritis dan Kreatif Siswa. Prosiding Seminar Nasional, 532-537.

Muzdalipah, I., \& Yulianto, E. (2015). Pengembangan Desain Pembelajaran Matematika untuk Siswa SD Berbasis Aktivitas Budaya dan Permainan Tradisional Masyarakat Kampung Naga. Jurnal Siliwangi, 1(1), 63-74.

Nadhilah, S., Purwoko, R. Y., Nugraheni, P., Purworejo, U. M., \& Purworejo, K. (2020). Analisis Kebutuhan Pengembangan E -Modul Berbasis Etnomatematika Produk Budaya Jawa Tengah, 4(2), 112-118.

Ndiung, S., Dantes, N., Ardana, I., \& Marhaeni, A. (2019). Treffinger Creative Learning Model with RME Principles on Creative Thinking Skill by Considering Numerical Ability. International Journal of Insruction, 12(3), 731-744. https://doi.org/10.29333/iji.2019.12344a

Ndiung, S., \& Jediut, M. (2020). Pengembangan instrumen tes hasil belajar matematika peserta didik sekolah dasar berorientasi pada berpikir tingkat tinggi. Premiere Educandum: Jurnal Pendidikan Dasar Dan Pembelajaran, 10(1), 94-111. https://doi.org/10.25273/pe.v10i1.6274

Ndiung, S., sariyasa, Jehadus, E., \& Apsari, R. ayu. (2021). The Effect of Treffinger Creative Learning Model with the Use RME Principles on Creative Thinking Skill and Mathematics Learning Outcome. International Journal of Insruction, 14(2), 873-888.

Ndiung, S., Sennen, E., Helmon, A., \& Jediut, M. (2020). Efektivitas Model Pembelajaran Treffinger dalam Menumbuhkan Keterampilan Berpikir Kreatif Peserta Didik Sekolah Dasar. Prisma, 9(2), 167-178.

Pratomo, W. D., Sunardo, A., \& Siskandar. (2016). Pengembangan Buku Pintar Elektronik Sebagai Media Pembelajaran untuk Siswa Sekolah Dasar. Indonesian Journal of Curriculum and Educational Technology Studies, 4(2), 66-72.

Richardo, R. (2016). Peran Ethnomatematika dalam Penerapan Pembelajaran Matematika. Almaata.Ac.Id, 7(2), 118-125.

Ripai, I., \& Sutarna, N. (2020). Implementasi Model Pembelajaran Problem Based Learning Berbantuan Macromedia Flash Untuk Meningkatkan Kemampuan Pemecahan Masalah Siswa Sekolah Dasar. Jurnal Cakrawala Pendas, 6(2), 130-137.

Rohmaini, L., Netriwati, Komarudin, Nendra, F., \& Qiftiyah, M. (2020). Pengembangan Modul Pembelajaran Matematika Berbasis Etnomatematika Berbantuan Wingeom Berdasarkan Langkah Borg and Gall. Teorema: Teori Dan Riset Matematika, 5(2), 176-186.

Rosilia, P., Yuniawatika, Y., \& Murdiyah, S. (2020). Analisis kebutuhan bahan ajar siswa di kelas III SDN Bendogerit 2 Kota Blitar. Premiere Educandum: Jurnal Pendidikan Dasar Dan Pembelajaran, 10(2), 125. https://doi.org/10.25273/pe.v10i2.6306

Sanders, S. (2016). Journal of Student Engagement : Education Matters Critical and Creative Thinkers in Mathematics Classrooms, 6(1), 19-27.

Scott, C. L. (2015). What Kind of Pedagogies for the 21st Century? Education Research and Foresight, 15(3), 1-21.

Sukmawarti, \& Pulungan, A. J. (2020). Pengembangan bahan ajr matematik SD bernunsa rumah adat Melayu. Jurnal Penelitian Pendidikan MIPA, 5(1), 31-36.

Tamur, M., Sennen, E., \& Pantaleon, K. V. (2017). Prosiding Seminar Nasional Metematiaka dan Pendidikan Matemtika. In Prosiding (pp. 15-21). Bandung, Universitas Pendidikan Indonesia (UPI): STKIP SILIWANGI.

Vale, I., \& Barbosa, A. (2015). Mathematics Creativity in Elementary Teacher Training. Journal of the European Teacher Education Network, 10, 101-109.

Wahyuni, A., Aji, A., Tias, W., \& Sani, B. (2013). Peran Etnomatematika dalam Membangun Karakter Bangsa: Penguatan Peran Matematika Dan Pendidikan Matematika Untuk Indonesia Yang Lebih Baik, (1), 111-118. 